Article

\title{
Syngas Production from Combined Steam Gasification of Biochar and a Sorption-Enhanced Water-Gas Shift Reaction with the Utilization of $\mathrm{CO}_{2}$
}

\author{
Supanida Chimpae ${ }^{1}$, Suwimol Wongsakulphasatch ${ }^{1}$, Supawat Vivanpatarakij ${ }^{2, * \mathbb{C} \text {, }}$ \\ Thongchai Glinrun ${ }^{3}$, Fasai Wiwatwongwana ${ }^{4}$, Weerakanya Maneeprakorn ${ }^{5}$ and \\ Suttichai Assabumrungrat ${ }^{6}$
}

1 Department of Chemical Engineering, Faculty of Engineering, King Mongkut's University of Technology North Bangkok, Bangkok 10800, Thailand; s5601031620023@email.kmutnb.ac.th (S.C.); suwimol.w@eng.kmutnb.ac.th (S.W.)

2 Energy Research Institute, Chulalongkorn University, Phayathai Road, Wang Mai, Phatumwan, Bangkok 10330, Thailand

3 Department of Petrochemical and Environmental Engineering, Faculty of Engineering, Pathumwan Institute of Technology, Rama 1 Road, Wang Mai, Phatumwan, Bangkok 10330, Thailand; thongchai@pit.ac.th

4 Department of Advanced Manufacturing Technology, Faculty of Engineering, Pathumwan Institute of Technology, 833 Rama 1 Road, Wangmai, Pathumwan, Bangkok 10330, Thailand; fasiaw227@gmail.com

5 National Nanotechnology Center (NANOTEC), National Science and Technology Development Agency (NSTDA), Pathum Thani 12120, Thailand; weerakanya@nanotec.or.th

6 Center of Excellence in Catalysis and Catalytic Reaction Engineering, Department of Chemical Engineering, Faculty of Engineering, Chulalongkorn University, Bangkok 10330, Thailand; Suttichai.A@chula.ac.th

* Correspondence: supawat.v@chula.ac.th

Received: 24 April 2019; Accepted: 1 June 2019; Published: 7 June 2019

\begin{abstract}
This research aims at evaluating the performance of a combined system of biochar gasification and a sorption-enhanced water-gas shift reaction (SEWGS) for synthesis gas production. The effects of mangrove-derived biochar gasification temperature, pattern of combined gasification and SEWGS, amount of steam and $\mathrm{CO}_{2}$ added as gasifying agent, and SEWGS temperature were studied in this work. The performances of the combined process were examined in terms of biochar conversion, gaseous product composition, and $\mathrm{CO}_{2}$ emission. The results revealed that the hybrid SEWGS using one-body multi-functional material offered a greater amount of $\mathrm{H}_{2}$ with a similar amount of $\mathrm{CO}_{2}$ emissions when compared with separated sorbent/catalyst material. The gasification temperature of $900{ }^{\circ} \mathrm{C}$ provided the highest biochar conversion of ca. $98.7 \%$. Synthesis gas production was found to depend upon the amount of water and $\mathrm{CO}_{2}$ added and SEWGS temperature. Higher amounts of $\mathrm{H}_{2}$ were observed when increasing the amount of water and the temperature of the SEWGS system.
\end{abstract}

Keywords: gasification; sorption-enhanced water-gas shift; multi-functional material

\section{Introduction}

Synthesis gas or syngas, which is composed mainly of $\mathrm{H}_{2}$ and $\mathrm{CO}$, can be applied for various downstream processes, e.g., electricity generation or chemical production [1-3]. The conversion of biomass by thermochemical processes such as gasification or pyrolysis has been extensively used to produce syngas and is recognized as an environmental-friendly technique as it is carbon-neutral [4]. The thermochemical process can be performed using different operating conditions, i.e., gasifying agent, temperature, pressure, etc., which could yield different amounts and compositions of syngas [5-7]. In addition, strategic techniques have also been applied for upgrading syngas, i.e., integrated gas-solid 
simultaneous gasification and catalytic reforming [8], a two-stage pyrolysis-reforming system [9], a two-stage gasification-reforming system [10], catalytic pyrolysis of biomass in a two-stage fixed bed reactor system [11], etc. For example, Chaiwatanodom et al. [6] studied the production of syngas from biomass gasification using recycled $\mathrm{CO}_{2}$ from the process as a gasifying agent by process modelling using the Aspen Plus program. The authors showed that the ratio of syngas production was varied depending upon amount of $\mathrm{CO}_{2}$ fed into the system, gasification temperature, and pressure. Waheed et al. [12] studied the production of hydrogen from biochar derived from sugar cane bagasse pyrolysis via steam catalytic gasification. Type of catalyst, gasification temperature, and steam flow rate were found to affect hydrogen yield.

Although biomass gasification has been proven to be one of the most efficient techniques for syngas production, one drawback of this technique is the production of $\mathrm{CO}_{2}$ in the product stream [13-16]. As is known, the release of $\mathrm{CO}_{2}$ is a cause of the greenhouse gas effect; storage or utilization of $\mathrm{CO}_{2}$ has therefore attracted interest worldwide. In our previous work [7], utilization of the released $\mathrm{CO}_{2}$ as a co-gasifying agent has been investigated for combined gasification with the steam reforming process via thermodynamic analysis using the Aspen Plus program. The results showed that the use of $\mathrm{CO}_{2}$ recycled from a separation process as a co-gasifying agent could enhance coal gas efficiency and reduce $\mathrm{CO}_{2}$ emissions. However, syngas composition was obtained differently depending upon combination pattern as well as reforming temperature and feed ratio; separation of $\mathrm{CO}_{2}$ after gasification process offered a higher $\mathrm{H}_{2} / \mathrm{CO}$ ratio when compared with the system that extracted $\mathrm{CO}_{2}$ after the reforming process. Higher reforming temperature and $\mathrm{H}_{2} \mathrm{O}$ feed can lead to higher production of $\mathrm{H}_{2}$. In this work, the combination of biochar gasification and the reforming process for syngas production is experimentally investigated using a packed-bed reactor system. Effects of combination pattern, operating temperature, feed ratio of gasifying agent, and amount of catalyst on syngas production and $\mathrm{CO}_{2}$ emission are examined. In addition, we have applied the concept of sorption-enhanced steam reforming by using a one-body multi-functional material, which contains $\mathrm{CO}_{2}$ sorbent and catalyst, to the reforming system with the purpose on improving process efficiency.

\section{Materials and Methods}

\subsection{Material Synthesis}

In this work, $12.5 \mathrm{wt} . \%$ of $\mathrm{Ni}$ on a $\gamma-\mathrm{Al}_{2} \mathrm{O}_{3}$ support was used as reforming catalyst, as it has been proven that it is suitable for steam reforming [17]. The material was prepared by the wet impregnation method using $\mathrm{Ni}\left(\mathrm{NO}_{3}\right)_{2} 6 \mathrm{H}_{2} \mathrm{O}$ as precursor. Firstly, $6.66 \mathrm{~g}$ of $\mathrm{Ni}\left(\mathrm{NO}_{3}\right)_{2} 6 \mathrm{H}_{2} \mathrm{O}$ was dissolved in $80 \mathrm{~mL}$ of deionized water, then $17.87 \mathrm{~g}$ of $\gamma-\mathrm{Al}_{2} \mathrm{O}_{3}$ was added into aqueous nickel nitrate solution and stirred at $80^{\circ} \mathrm{C}$ until the water was almost completely evaporated. The solid was dried at $120^{\circ} \mathrm{C}$ overnight and calcined at $600{ }^{\circ} \mathrm{C}$ for $3 \mathrm{~h}$ in air.

$\mathrm{CaO}$ on $\mathrm{Al}_{2} \mathrm{O}_{3}$ support, named $\mathrm{CaO} / \mathrm{Ca}_{12} \mathrm{Al}_{14} \mathrm{O}_{33}$, was used as $\mathrm{CO}_{2}$ adsorbent as it offers high $\mathrm{CO}_{2}$ sorption capacity in the temperature range of steam reforming [18]. In this work, $\mathrm{CaO} / \mathrm{Ca}_{12} \mathrm{Al}_{14} \mathrm{O}_{33}$ was synthesized by the sol-gel method using $\mathrm{Al}\left(\mathrm{NO}_{3}\right)_{3} 9 \mathrm{H}_{2} \mathrm{O}$ and $\mathrm{Ca}\left(\mathrm{NO}_{3}\right)_{2} 4 \mathrm{H}_{2} \mathrm{O}$ as precursors. To prepare this sorbent, $4.22 \mathrm{~g}$ of $\mathrm{Ca}\left(\mathrm{NO}_{3}\right)_{2} 4 \mathrm{H}_{2} \mathrm{O}$ was mixed with $2.31 \mathrm{~g}$ of $\mathrm{Al}\left(\mathrm{NO}_{3}\right)_{3} 9 \mathrm{H}_{2} \mathrm{O}$ in DI (deionized) water. Then, $5.02 \mathrm{~g}$ of citric acid were added into the solution, which was stirred at $80^{\circ} \mathrm{C}$ for $7 \mathrm{~h}$. After that, the mixture was placed at ambient temperature for $18 \mathrm{~h}$ to form wet gel. Later, the wet gel was dried at $80^{\circ} \mathrm{C}$ for $5 \mathrm{~h}$ and at $110^{\circ} \mathrm{C}$ for $12 \mathrm{~h}$, respectively, followed by calcination at $850^{\circ} \mathrm{C}$ for $2 \mathrm{~h}$ under dried air. At this stage, $\mathrm{CaO} / \mathrm{Ca}_{12} \mathrm{Al}_{14} \mathrm{O}_{33}$ containing $\mathrm{CaO}: \mathrm{Ca}_{12} \mathrm{Al}_{14} \mathrm{O}_{33}=70: 30 \mathrm{wt} . \%$ was obtained.

One-body multi-functional sorbent/catalyst material, designated as xwt. $\% \mathrm{NiO} / \mathrm{CaO}-\mathrm{Ca}_{12} \mathrm{Al}_{14} \mathrm{O}_{33}$, was prepared by sol-gel method following Changjun et al. [19]. In brief, $3.11 \mathrm{~g}$ of $\mathrm{Ni}\left(\mathrm{NO}_{3}\right)_{2} 6 \mathrm{H}_{2} \mathrm{O}$, $5.69 \mathrm{~g}$ of $\mathrm{Al}\left(\mathrm{NO}_{3}\right)_{3} 9 \mathrm{H}_{2} \mathrm{O}$, and $17.81 \mathrm{~g}$ of $\left.\mathrm{Ca}\left(\mathrm{NO}_{3}\right)_{2} 4 \mathrm{H}_{2} \mathrm{O}\right)$, were dissolved in $109 \mathrm{~mL}$ of DI water with the addition of citric acid using a molar ratio of citric acid to $\mathrm{Al}^{3+}, \mathrm{Ni}^{2+}, \mathrm{Ca}^{2+}$ equal to 1.2:1:1:1. The solution was adjusted to $\mathrm{pH} 1-2$ by nitric acid. Then, the solution was heated up and stirred at 
$80^{\circ} \mathrm{C}$ under reflux for $2 \mathrm{~h}$. After that, ethylene glycol (mass ratio polyethylene glycol to citric acid of 0.5 ) was added into the solution, and stirred under reflux at $105^{\circ} \mathrm{C}$ for $5 \mathrm{~h}$. The solution was thereafter dried in an oven at $110^{\circ} \mathrm{C}$ for $12 \mathrm{~h}$ and calcined at $850{ }^{\circ} \mathrm{C}$ for $2 \mathrm{~h}$ under dried air.

\subsection{Material Characterization}

Synthetic materials were characterized their compositions and crystallinity by the X-ray diffraction (XRD) technique; Bruker model D8 Advance (Bruker Crop., Billerica, MA, USA). Surface area, pore size, and pore volume were investigated by $\mathrm{N}_{2}$ adsorption/desorption isotherm by Brunauer-Emmett-Teller (BET) technique; Micromeritics model 3Flex (Micrometrics Instrument Corp., Norcross, GA, USA). Morphologies of the samples were determined by a scanning electron microscope (SEM); Hitachi model S-3400N (Hitachi High-Technologies Corp., Tokyo, Japan).

\subsection{Syngas Production Test}

Syngas production experiments were carried out by using two-connected fixed-bed reactors, one for biomass gasification and the other for reforming reaction (see Figure 1). Prior to running experiment, biochar was pretreated by Ar with a flow rate of $50 \mathrm{~mL} / \mathrm{min}$ at $600{ }^{\circ} \mathrm{C}$ for $60 \mathrm{~min}$. Sorbent and catalyst materials were pretreated by Ar with a flow rate of $50 \mathrm{~mL} / \mathrm{min}$ at $850{ }^{\circ} \mathrm{C}$ for 30 min followed by the same flow rate of $\mathrm{H}_{2}$ at $850^{\circ} \mathrm{C}$ for $30 \mathrm{~min}$, respectively. In this work, gasification temperature was varied between $850{ }^{\circ} \mathrm{C}$ and $950^{\circ} \mathrm{C}$ and that of reforming was varied between $500{ }^{\circ} \mathrm{C}$ and $650{ }^{\circ} \mathrm{C}$ under atmospheric pressure. The gasifying agent was fed at a fixed ratio of $\mathrm{O}_{2}$ and $\mathrm{C}$, whereas $\mathrm{CO}_{2}$ and $\mathrm{H}_{2} \mathrm{O}$ were varied. The $\mathrm{CO}_{2} / \mathrm{O}_{2} / \mathrm{H}_{2} \mathrm{O} / \mathrm{C}$ feed ratios were varied in the range of 0-0.5:0.125:0-1.5:1. All experiments were carried out by fixing total feed flow rate to yield gas hourly space velocity (GHSV) ca. $700 \mathrm{~h}^{-1}$.

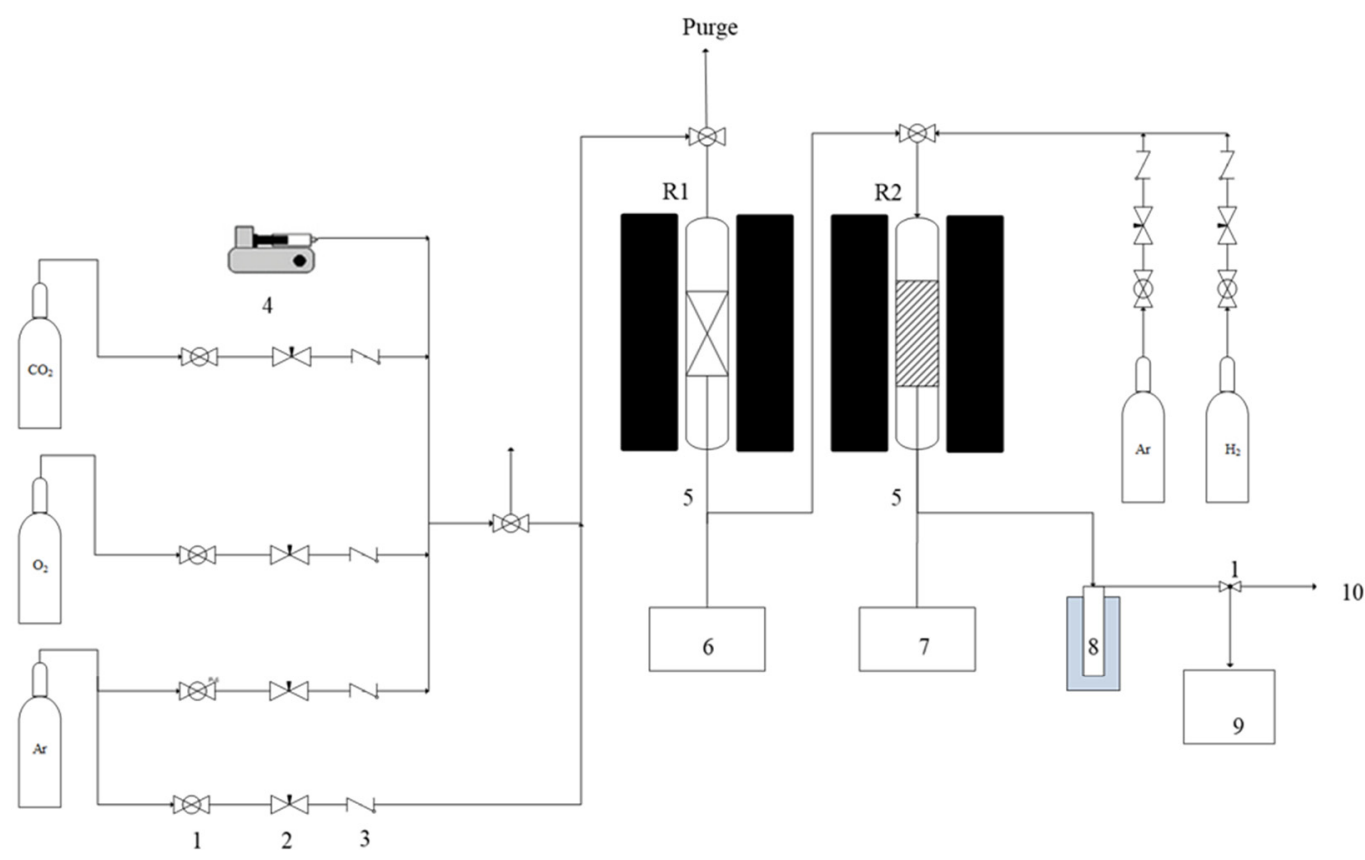

\begin{tabular}{lllll}
\hline 1.Globe valve & 2.Needle valve & 3.Check valve & 4.Syringe pump & 5.Thermocouple \\
6.Temperature controller $(\mathrm{R} 1)$ & 7.Temperature controller $(\mathrm{R} 2)$ & 8.Condenser & 9.Gas Chromatography (GC) & 10.Flow meter
\end{tabular}

Figure 1. Schematic diagram of experimental setup for syngas production.

Performances of the combined process were determined in terms of biochar conversion (\%Biochar conversion), ratio of $\mathrm{H}_{2} / \mathrm{CO}$ in the produced syngas $\left(\mathrm{H}_{2} / \mathrm{CO}\right.$ ratio), and $\mathrm{CO}_{2}$ emission ratio $\left(\mathrm{CO}_{2} \mathrm{EMR}\right)$ as defined as follows: 
\%Biochar conversion:

$$
\% \text { Biochar conversion }=\frac{{\text { mole of } \text { biochar }_{\text {in }}-\text { mole of }_{\text {biochar }} \text { out }}_{\text {mole of biochar }} \text { in }}{\text { bin }} \times 100
$$

$\mathrm{H}_{2} / \mathrm{CO}$ ratio:

$$
\mathrm{H}_{2} / \mathrm{CO} \text { ratio }=\frac{\text { mole of } \mathrm{H}_{2} \text { produced }}{\text { mole of } \mathrm{CO} \text { produced }}
$$

$\mathrm{CO}_{2}$ emission ratio, $\mathrm{CO}_{2} \mathrm{EMR}$ :

$$
\mathrm{CO}_{2} \text { emission ratio }\left(\mathrm{CO}_{2} \mathrm{EMR}\right)=\frac{\text { mole of } \mathrm{CO}_{2} \text { emission from } \mathrm{CO}_{2} \text { outlets }}{\text { mole of } \mathrm{CO}_{2} \text { total }}
$$

where $\mathrm{CO}_{2}$ total is the amount of $\mathrm{CO}_{2}$ produced from the gasifier.

\section{Results and Discussions}

\subsection{Effect of Gasification Temperature}

Conversion of biochar was firstly investigated by studying the effect of gasification temperature using $\mathrm{H}_{2} \mathrm{O}$ and $\mathrm{O}_{2}$ as gasifying agents with a $\mathrm{H}_{2} \mathrm{O}: \mathrm{O}_{2}: \mathrm{C}$ feed molar ratio of $0.25: 0.25: 1$. As shown in Figure 2, high biochar conversions of $97.5 \%, 98.7 \%$, and $98.1 \%$ could be obtained by gasification at temperatures of $850{ }^{\circ} \mathrm{C}, 900{ }^{\circ} \mathrm{C}$, and $950{ }^{\circ} \mathrm{C}$, respectively. The results confirm that this temperature range is suitable for biochar gasification.

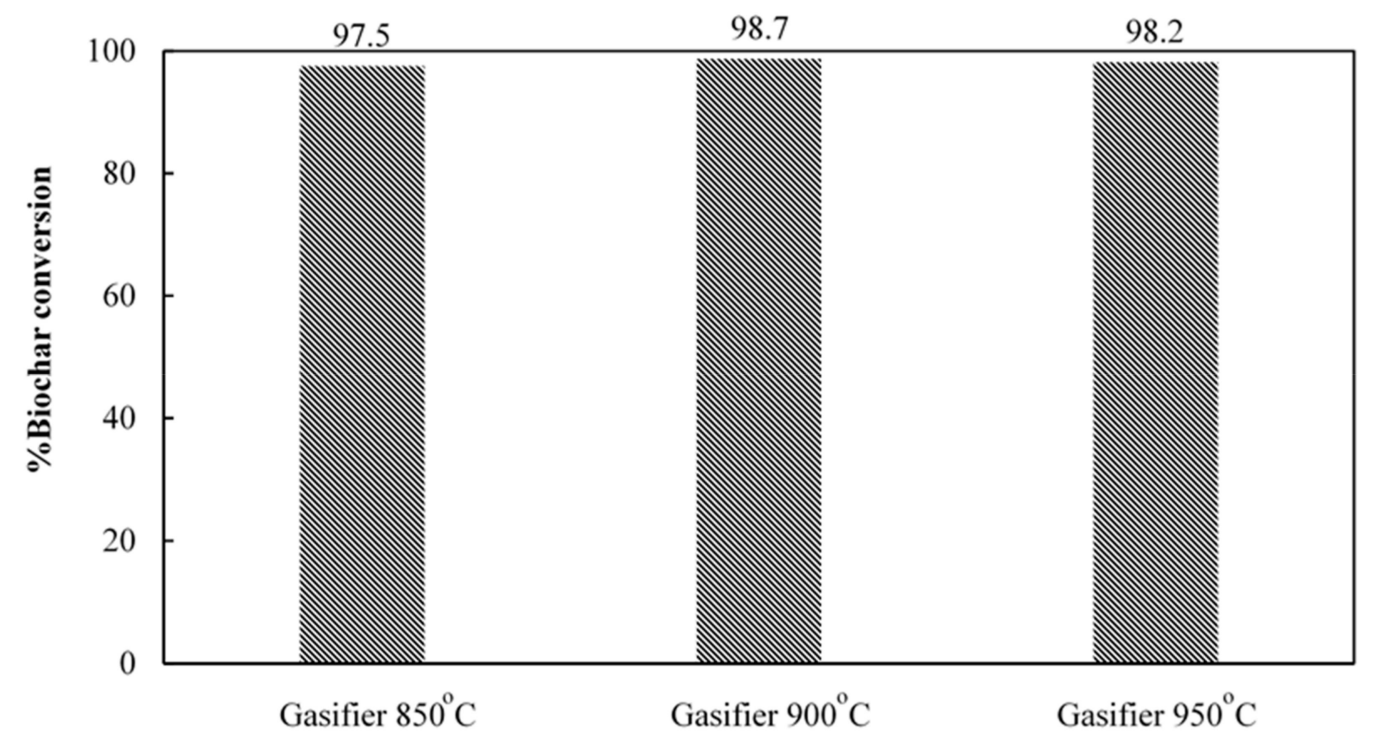

Figure 2. \%Biochar conversion at different gasification temperatures using a $\mathrm{H}_{2} \mathrm{O}: \mathrm{O}_{2}: \mathrm{C}$ feed molar ratio of $0.25: 0.25: 1$.

Product compositions obtained from the gasifier at different temperatures are shown in Figure 3. For the range of gasification temperature investigated in this work, two main products, $\mathrm{CO}$ and $\mathrm{CO}_{2}$, are obtained. The obtained products could be due to the water-gas reaction (Equation (4)) and the partial oxidation reaction (Equation (5)).

Water gas reaction

$$
\mathrm{C}(\mathrm{s})+\mathrm{H}_{2} \mathrm{O}(\mathrm{g}) \rightleftharpoons \mathrm{CO}(\mathrm{g})+\mathrm{H}_{2}(\mathrm{~g}) \quad \Delta H=131 \mathrm{~kJ} / \mathrm{kmol}
$$


Partial oxidation reaction

$$
2 \mathrm{C}(\mathrm{s})+\mathrm{O}_{2}(\mathrm{~g}) \rightleftharpoons 2 \mathrm{CO}(\mathrm{g}) \quad \Delta H=-221 \mathrm{~kJ} / \mathrm{kmol}
$$

Increasing gasification temperature from $850{ }^{\circ} \mathrm{C}$ to $950{ }^{\circ} \mathrm{C}$ shows insignificant effects on the production of $\mathrm{H}_{2}$, whereas a gradual increase of $\mathrm{CO}$ production is observed with the reduction of $\mathrm{CO}_{2}$. This phenomenon could be attributed to the result of a favorable Boudouard reaction (Equation (6)) [12,20]:

Boudouard reaction

$$
\mathrm{C}(\mathrm{s})+\mathrm{CO}_{2}(\mathrm{~g}) \rightleftharpoons 2 \mathrm{CO}(\mathrm{g}) \quad \Delta \mathrm{H}=172 \mathrm{~kJ} / \mathrm{kmol}
$$

As seen from the above results, very small amounts of hydrogen can be obtained with solely biochar gasification. As a consequence, upgrading hydrogen production would further investigated by combining with steam reforming reaction. For gasification reaction, it was shown that almost complete conversion of biochar can be obtained in the range of gasification temperature investigated in this work, $850{ }^{\circ} \mathrm{C}$ to $950{ }^{\circ} \mathrm{C}$. For optimistic reasons, a gasification temperature of $900{ }^{\circ} \mathrm{C}$ was chosen for investigating other effects on syngas production.

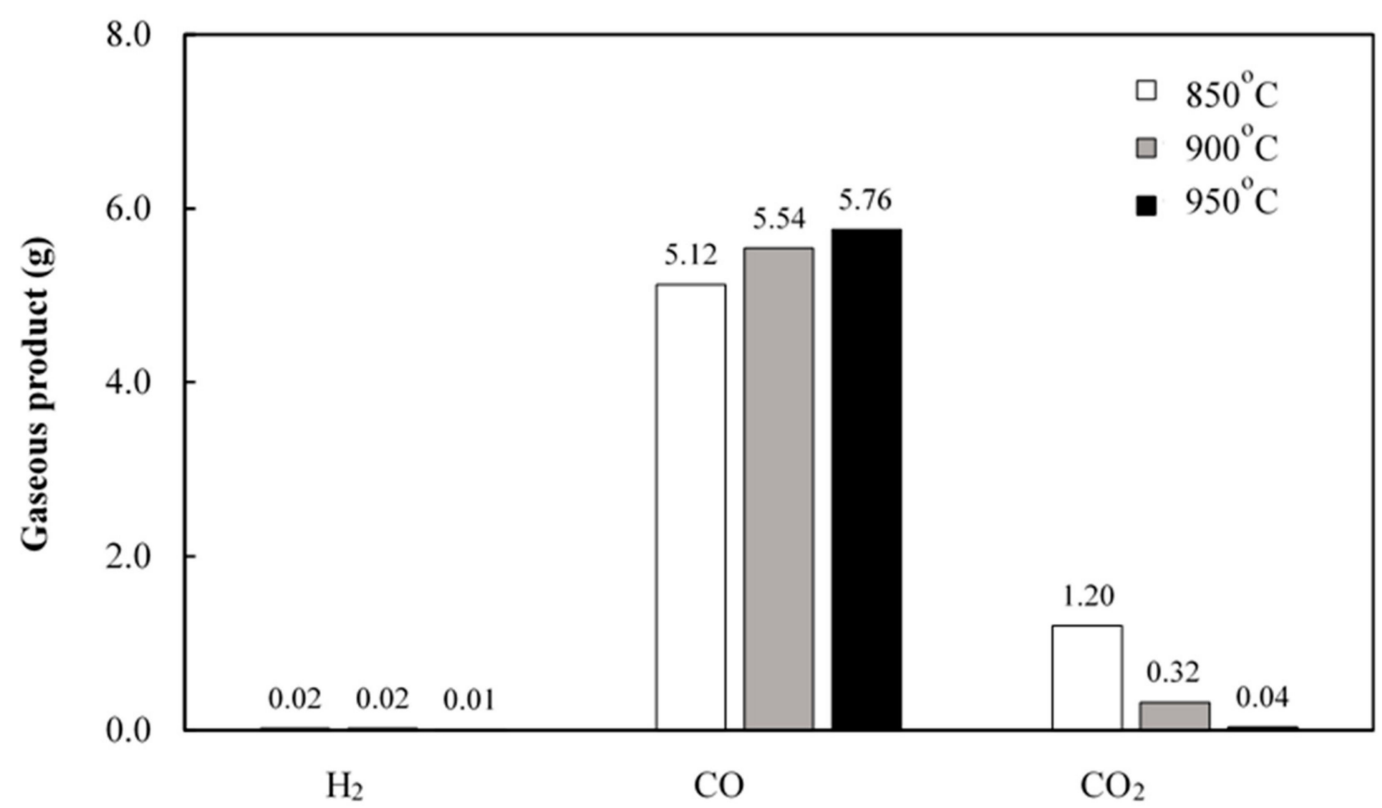

Figure 3. Gasification of biochar at different gasification temperatures $\left(\mathrm{H}_{2} \mathrm{O}: \mathrm{O}_{2}: \mathrm{C}\right.$ feed molar ratio of 0.25:0.25:1 under atmospheric pressure).

\subsection{Effect of Combined Gasification and Reforming Reaction}

As shown in the previous section, biochar gasification can yield insignificant amount of $\mathrm{H}_{2}$, to enhance the production of $\mathrm{H}_{2}$, reforming reactor was introduced into the gasification system. In this investigation, to prove the concept of our simulation works [7] and to introduce process integration concept, three different packing patterns of sorbent and catalyst were studied, as shown in Figure 4 . In Figure 4a, the catalyst and the sorbent were packed separately and the catalyst was packed on top of the sorbent, designated as the combined biomass gasifier and water-gas shift with $\mathrm{Post}_{-} \mathrm{CO}_{2}$ recycle (CBGR-Post $\mathrm{CO}_{2}$ ). In Figure $4 \mathrm{~b}$, the sorbent was placed on top of the catalyst, designated as the combined biomass gasifier and water-gas shift with Pre- $\mathrm{CO}_{2}$ recycle $(\mathrm{CBGR}-\mathrm{PreCO})_{2}$, and in Figure $4 \mathrm{c}$ the developed one-body of combined catalyst with sorbent was introduced into the system, designated as the combined biomass gasifier and water-gas shift with multifunctional- $\mathrm{CO}_{2}$ recycle $\left(\mathrm{CBGR}-\mathrm{SimulCO} \mathrm{C}_{2}\right)$. In order to utilize $\mathrm{CO}_{2}$, in this section, $\mathrm{CO}_{2}$ was also used as co-gasifying agent 
together with $\mathrm{H}_{2} \mathrm{O}$ and $\mathrm{O}_{2}$. In this work, performances of each combined system were investigated in terms of syngas production and $\mathrm{CO}_{2}$ emission ratio at a fixed gasification temperature of $900{ }^{\circ} \mathrm{C}$, reforming temperature of $600{ }^{\circ} \mathrm{C}, \mathrm{H}_{2} \mathrm{O}: \mathrm{CO}_{2}: \mathrm{O}_{2}: \mathrm{C}$ feed molar ratio of 0.5:0.5:0.125:1, and $\mathrm{NiO}$ content of 12.5 wt. $\%$.

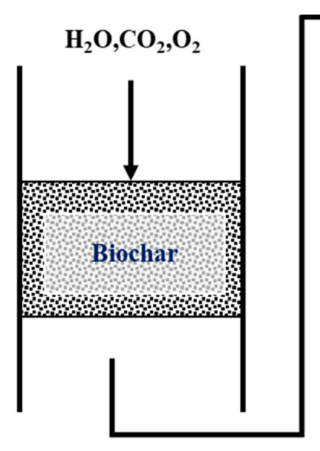

$\mathrm{CO}, \mathrm{CH}_{4}, \mathrm{CO}_{2}, \mathrm{H}_{2}$

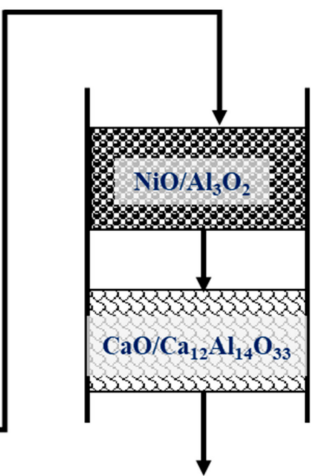

Gaseous product

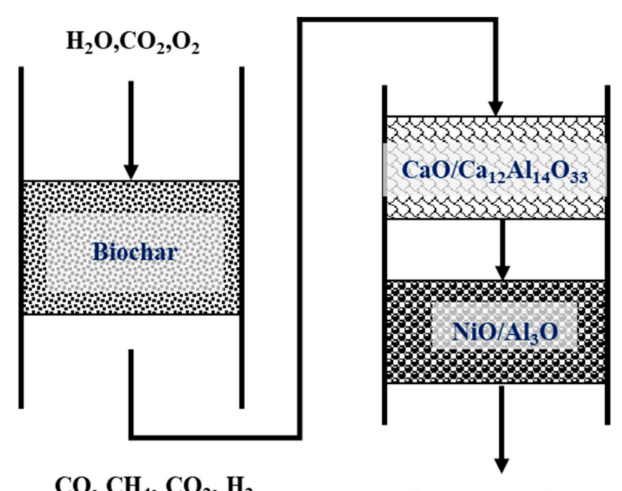

$\mathrm{CO}, \mathrm{CH}_{4}, \mathrm{CO}_{2}, \mathrm{H}_{2}$
Gaseous product
CBGR-PostCO

(a)

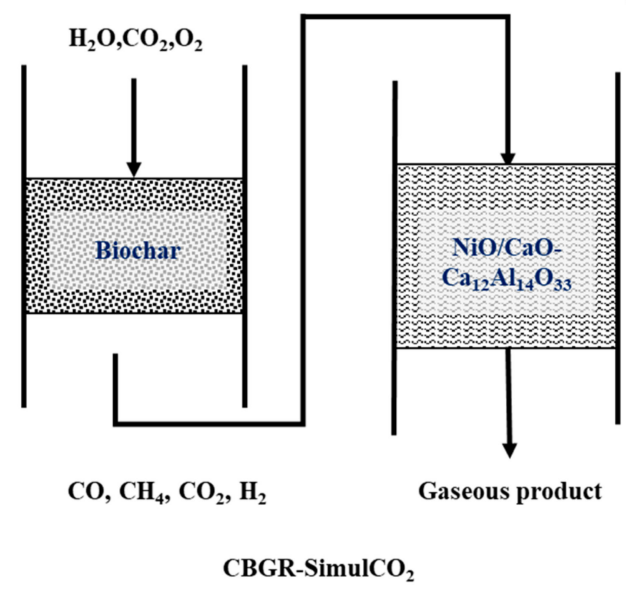

CBGR-PreCO

(b)

(c)

Figure 4. Patterns of sorbent and catalyst packing in the water-gas shift reactor (a) $\mathrm{CBGR}-\mathrm{PostCO}_{2}$, (b) CBGR-PreCO $\mathrm{C}_{2}$, and (c) CBGR-SimulCO 2 .

Prior to running experiments, compositions of biochar were determined by proximate and ultimate analysis (Table 1). Compositions and surface textural properties of the synthetic materials were examined by XRD (Figure 5) and BET surface area analysis (Table 2), respectively. The results show XRD peaks corresponding to $\mathrm{CaO}$ at $2 \theta=32.204,37.347$, and 64.154, $\mathrm{Ca}_{12} \mathrm{Al}_{14} \mathrm{O}_{33}$ at $2 \theta=18.052$, 54.972 , and 62.634, and $\mathrm{NiO}$ at $2 \theta=37.249,43.297,62.934$, and $67.271[17,21]$. Note that $\mathrm{Ca}(\mathrm{OH})_{2} \mathrm{peaks}$, which are assigned at $2 \theta=28.672,34.102$, and 47.121, are observed in the XRD pattern due to the fact that $\mathrm{CaO}$ is a hygroscopic material. The BET surface area of $12.5 \mathrm{wt}$.\% NiO/CaO-Ca $12 \mathrm{Al}_{14} \mathrm{O}_{33}$ is 13.5 $\mathrm{m}^{2} / \mathrm{g}$, that of $\mathrm{CaO}-\mathrm{Ca}_{12} \mathrm{Al}_{14} \mathrm{O}_{33}$ is $5.91 \mathrm{~m}^{2} / \mathrm{g}$, and that of $12.5 \mathrm{wt} . \% \mathrm{NiO} / \mathrm{Al}_{2} \mathrm{O}_{3}$ is $59.1 \mathrm{~m}^{2} / \mathrm{g}$, respectively.

Table 1. Proximate and ultimate analysis results of biochar.

\begin{tabular}{cccc}
\hline \multicolumn{2}{c}{ Proximate (wt.\%) } & \multicolumn{2}{c}{ Ultimate (wt.\%) } \\
\hline Moisture & 5.30 & $\mathrm{C}$ & 80.20 \\
Volatile matters & 36.26 & $\mathrm{H}$ & 2.83 \\
Fixed carbon & 56.40 & $\mathrm{O}$ (balance) & 16.39 \\
Ash & 2.05 & $\mathrm{~N}$ & 0.58 \\
\hline
\end{tabular}




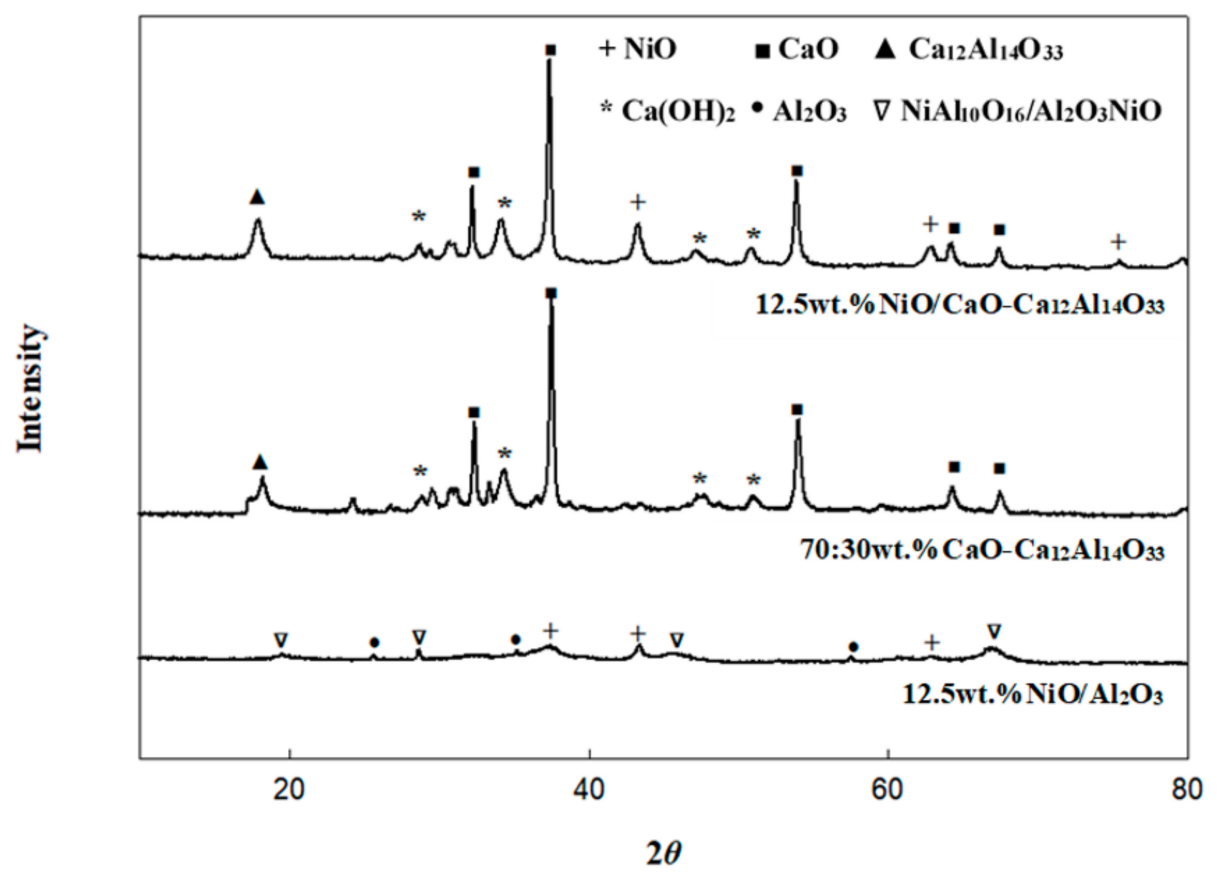

Figure 5. XRD patterns of $\mathrm{NiO} / \mathrm{Al}_{2} \mathrm{O}_{3}, \mathrm{CaO} / \mathrm{Ca}_{12} \mathrm{Al}_{14} \mathrm{O}_{33}$, and 12.5 wt. $\% \mathrm{Ni} / \mathrm{CaO}-\mathrm{Ca}_{12} \mathrm{Al}_{14} \mathrm{O}_{33}$.

Table 2. Physical properties of materials from BET measurements.

\begin{tabular}{cccc}
\hline Sample & Surface Area $\left(\mathbf{m}^{2} / \mathbf{g}\right)$ & Pore Volume $\left(\mathbf{c m}^{\mathbf{3}} / \mathbf{g}\right)$ & Pore Size $(\mathbf{n m})$ \\
\hline 12.5 wt. $\% \mathrm{NiO} / \mathrm{Al}_{2} \mathrm{O}_{3}$ & 59.1 & 0.150 & 0.09 \\
$\mathrm{CaO}-\mathrm{Ca}_{12} \mathrm{Al}_{14} \mathrm{O}_{33}$ & 5.91 & 0.009 & 0.13 \\
12.5 wt. $\% \mathrm{NiO} / \mathrm{CaO}-\mathrm{Ca}_{12} \mathrm{Al}_{14} \mathrm{O}_{33}$ & 13.5 & 0.016 & 0.16 \\
\hline
\end{tabular}

As shown in Figure 6, the addition of reforming system (regardless of combination pattern) can provide higher $\mathrm{H}_{2}$ production when compared with solely gasification reaction shown in Section 3.1. This could be due to the result of water-gas shift reaction (Equation (7)), where the main gasification product, $\mathrm{CO}$, is further reacted with steam to form $\mathrm{H}_{2}$ and $\mathrm{CO}_{2}$ in the steam reforming reactor.

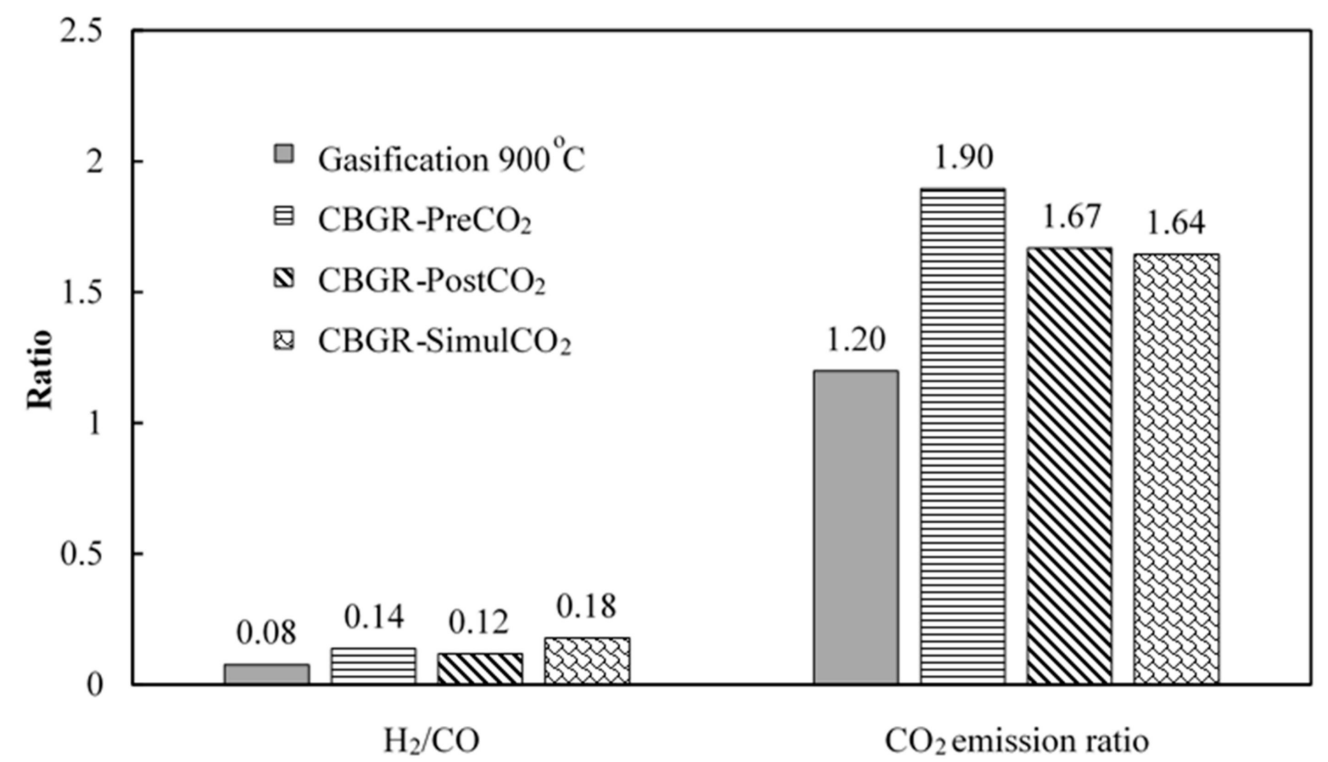

Figure 6. $\mathrm{H}_{2} / \mathrm{CO}$ and $\mathrm{CO}_{2}$ emission ratio from different proposed systems $\left(\mathrm{H}_{2} \mathrm{O}: \mathrm{CO}_{2}: \mathrm{O}_{2}: \mathrm{C}\right.$ feed molar ratio of 0.5:0.5:0.125:1, gasification at $900{ }^{\circ} \mathrm{C}$, reforming at $600{ }^{\circ} \mathrm{C}$ and ambient pressure). 
Water-gas shift reaction

$$
\mathrm{CO}(\mathrm{g})+\mathrm{H}_{2} \mathrm{O}(\mathrm{g}) \rightleftharpoons \mathrm{CO}_{2}(\mathrm{~g})+\mathrm{H}_{2}(\mathrm{~g}) \quad \Delta H=-41 \mathrm{~kJ} / \mathrm{kmol}
$$

Combining gasification with reforming system in different patterns shows the effect on syngas production and $\mathrm{CO}_{2}$ emission ratio as demonstrated in Figure 6. The CBGR-PreCO $\mathrm{C}_{2}$ offers higher $\mathrm{H}_{2}$ than the CBGR-Post $\mathrm{CO}_{2}$, which is in good agreement with our simulation results proposed previously [7]. The enhancement of $\mathrm{H}_{2}$ is believed to be mainly due to the result of the water-gas shift reaction. For the $\mathrm{CBGR}-\mathrm{PreCO}_{2}$ system, $\mathrm{CO}_{2}$ was removed from the system prior to the water-gas shift reaction, leading to a favorable forward water-gas shift reaction. On the other hand, the $\mathrm{CO}_{2}$ emission from CBGR-PreCO $\mathrm{C}_{2}$ is higher than $\mathrm{CBGR}-\mathrm{Post}_{\mathrm{CO}}$. This could be because the produced $\mathrm{CO}_{2}$ is partly adsorbed by CaO-based sorbent in the CBGR-PostCO ${ }_{2}$ system. Overall, the CBGR-SimulCO system offers the highest $\mathrm{H}_{2}$ production when compared with the $\mathrm{CBGR}-\mathrm{PreCO}_{2}$ system and the CBGR-PostCO $\mathrm{C}_{2}$ systems. This observation is due to the effect of the sorption-enhanced water-gas shift reaction; simultaneous removal of $\mathrm{CO}_{2}$ can overcome the limitation of water-gas shift reaction (SEWGS) by inducing the system to proceed forward according to Le Chatelier's principle. More interestingly, the $\mathrm{CO}_{2}$ emission ratio of the CBGR-SimulCO $\mathrm{C}_{2}$ system is found to be minimal, which could be attributed to greater $\mathrm{CO}_{2}$ sorption capacity as mass transfer is favorable in the case of using one-body multi-functional material.

$\mathrm{CO}_{2}$ adsorption

$$
\mathrm{CaO}(\mathrm{s})+\mathrm{CO}_{2}(\mathrm{~g}) \rightleftharpoons \mathrm{CaCO}_{3}(\mathrm{~s}) \quad \Delta \mathrm{H}=-178.2 \mathrm{~kJ} / \mathrm{kmol}
$$

As seen above, applying sorption-enhanced reaction $\left(\mathrm{CBGR}-\mathrm{SimulCO}_{2}\right)$ system by introducing one-body multi-functional material can slightly increase $\mathrm{H}_{2} / \mathrm{CO}$ with the reduction of the $\mathrm{CO}_{2}$ emission from the system when compared with other sorption systems. However, all patterns provide $\mathrm{H}_{2} / \mathrm{CO}$ ratios less than 0.18 . This might be due to this biochar ( $\mathrm{H}$ content is $2.83 \mathrm{wt} . \%$ from the ultimate analysis result, Table 1) not being favorable as feedstock for the production of syngas containing high hydrogen content. Nevertheless, the effect of operating conditions, including amount of catalyst, sorption-enhanced reaction temperature, and feed ratio of gasifying agent, were investigated for the combined gasification with SEWGS system.

\subsection{Effect of Catalyst Amount}

In this section, the effect of amount of catalyst on gaseous production, syngas $\mathrm{H}_{2} / \mathrm{CO}$ ratio, and $\mathrm{CO}_{2}$ emission ratio was studied. Figure 7 shows compositions of gaseous product for different wt.\% of $\mathrm{NiO}$. Comparative amounts of hydrogen production are obtained for all $\mathrm{NiO}$ contents, whereas the maximum of $\mathrm{CO}$ production is found with $12.5 \mathrm{wt} . \% \mathrm{Ni} / \mathrm{CaO}-\mathrm{Ca}_{12} \mathrm{Al}_{14} \mathrm{O}_{33}$. This result could be because the $12.5 \mathrm{wt} . \% \mathrm{Ni} / \mathrm{CaO}-\mathrm{Ca}_{12} \mathrm{Al}_{14} \mathrm{O}_{33}$ possesses the highest $\mathrm{BET}$ surface area, resulting in higher active surface exposure, as shown in Table 3. Large amount of $\mathrm{NiO}(17.5 \mathrm{wt} . \%)$ could block the small pores of the support, leading to the reduction of surface area as well as pore volume with an increase of average pore size diameter. For the $7.5 \mathrm{wt} . \% \mathrm{Ni} / \mathrm{CaO}-\mathrm{Ca}_{12} \mathrm{Al}_{14} \mathrm{O}_{33}$, small amounts of $\mathrm{Ni}$ cannot help prevent the agglomeration of $\mathrm{CaO}$ particles, resulting in lower surface area (Table 3 ) and dense packing particles (Figure 8).

Table 3. Physical properties of multi-functional materials for different $\mathrm{NiO}$ contents.

\begin{tabular}{cccc}
\hline Sample & Surface Area $\left(\mathbf{m}^{2} / \mathbf{g}\right)$ & Pore Volume $\left(\mathbf{c m}^{3} / \mathbf{g}\right)$ & Pore Size $(\mathbf{n m})$ \\
\hline 7.5 wt. $\% \mathrm{NiO} / \mathrm{CaO}-\mathrm{Ca}_{12} \mathrm{Al}_{14} \mathrm{O}_{33}$ & 11.70 & 0.026 & 0.11 \\
12.5 wt. $\% \mathrm{NiO} / \mathrm{CaO}-\mathrm{Ca}_{12} \mathrm{Al}_{14} \mathrm{O}_{33}$ & 13.50 & 0.016 & 0.16 \\
17.5 wt. $\% \mathrm{NiO} / \mathrm{CaO}-\mathrm{Ca}_{12} \mathrm{Al}_{14} \mathrm{O}_{33}$ & 12.45 & 0.023 & 0.11 \\
\hline
\end{tabular}




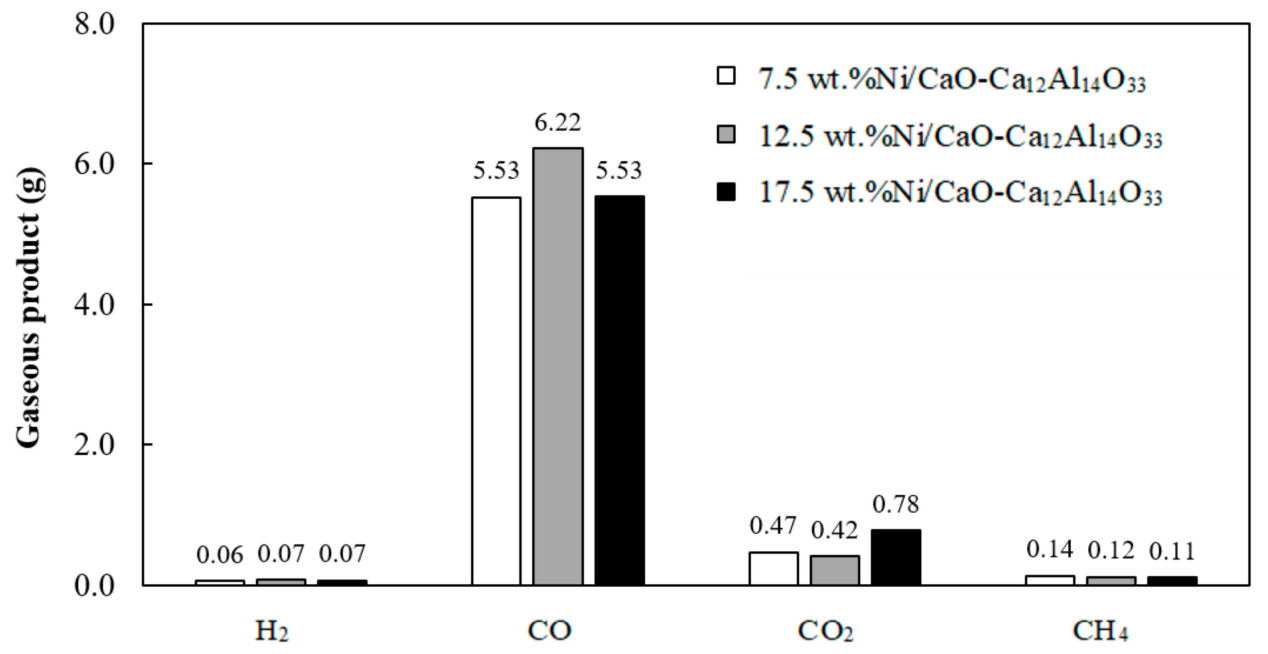

Figure 7. Product composition at different wt. $\%$ of $\mathrm{Ni}$ on $\mathrm{Ni} / \mathrm{CaO}-\mathrm{Ca}_{12} \mathrm{Al}_{14} \mathrm{O}_{33}$ using a $\mathrm{H}_{2} \mathrm{O}: \mathrm{CO}_{2}: \mathrm{O}_{2}: \mathrm{C}$ feed molar ratio of 0.5:0.1:0.125:1, gasification at $900{ }^{\circ} \mathrm{C}$, and sorption-enhanced water-gas shift reaction (SEWGS) at $600{ }^{\circ} \mathrm{C}$.
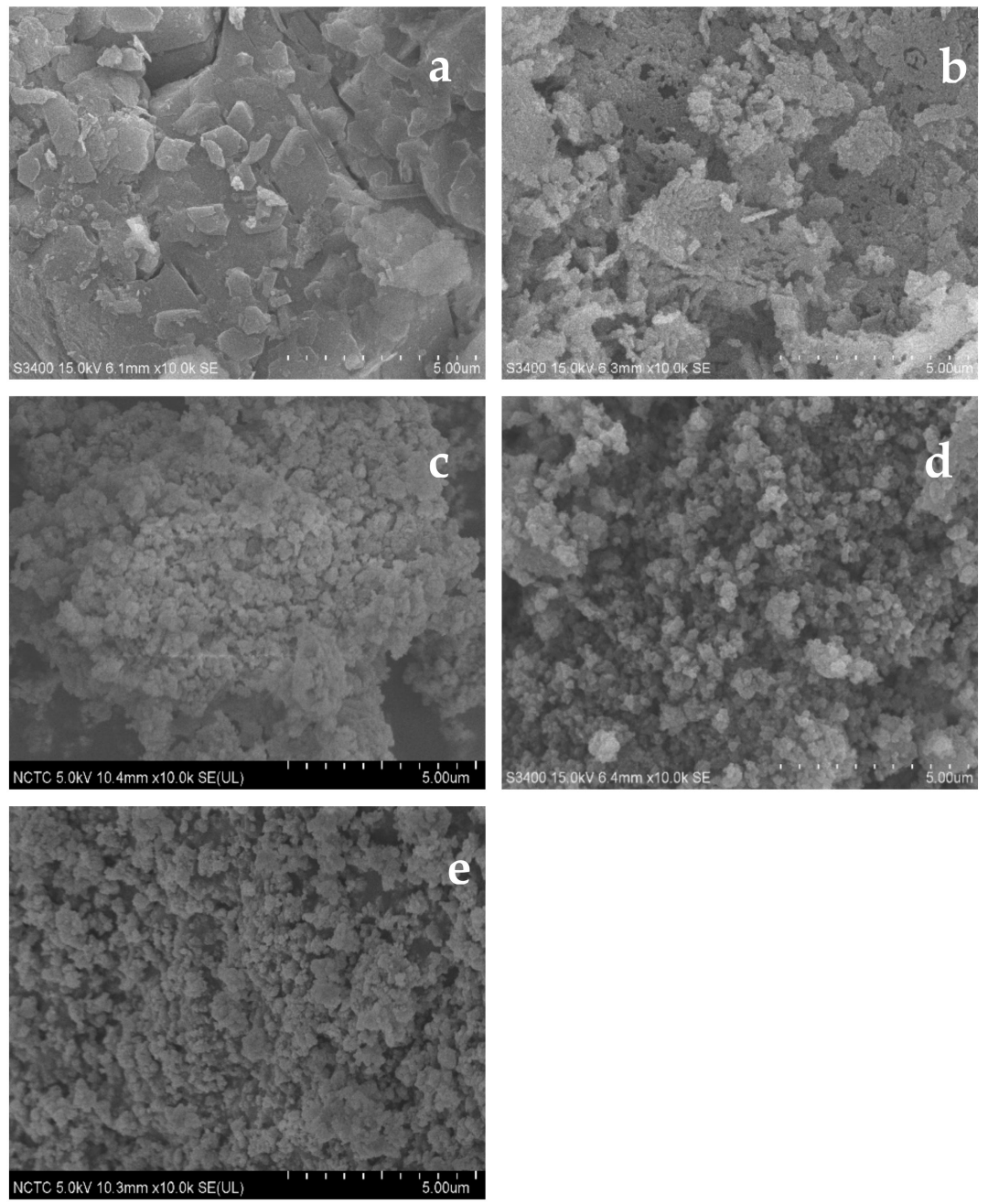

Figure 8. SEM images of fresh sample materials; (a) $\mathrm{Ni} / \mathrm{Al}_{2} \mathrm{O}_{3}$, (b) $\mathrm{CaO}-\mathrm{Ca}_{12} \mathrm{Al}_{14} \mathrm{O}_{33}$, (c) 7.5 wt.\% $\mathrm{Ni} / \mathrm{CaO}-\mathrm{Ca}_{12} \mathrm{Al}_{14} \mathrm{O}_{33}$, (d) 12.5 wt. $\%$ Ni/CaO-Ca ${ }_{12} \mathrm{Al}_{14} \mathrm{O}_{33}$, and (e) 17.5 wt.\% Ni/CaO-Ca ${ }_{12} \mathrm{Al}_{14} \mathrm{O}_{33}$.

Figure 9 shows $\mathrm{CO}_{2}$ emission ratio of different $\mathrm{NiO}$ contents. The results show that the $12.5 \mathrm{wt} . \%$ $\mathrm{Ni} / \mathrm{CaO}-\mathrm{Ca}_{12} \mathrm{Al}_{14} \mathrm{O}_{33}$ provides minimum $\mathrm{CO}_{2}$ emission ratio, which could be due to the result of high 
performance of SEWGS reaction. Lower $\mathrm{CO}_{2}$ adsorption observed with the $7.5 \mathrm{wt} . \% \mathrm{Ni} / \mathrm{CaO}-\mathrm{Ca}_{12} \mathrm{Al}_{14} \mathrm{O}_{33}$ and the $17.5 \mathrm{wt} . \% \mathrm{Ni} / \mathrm{CaO}-\mathrm{Ca}_{12} \mathrm{Al}_{14} \mathrm{O}_{33}$ could be attributed to lower surface area as shown in Table 3 .

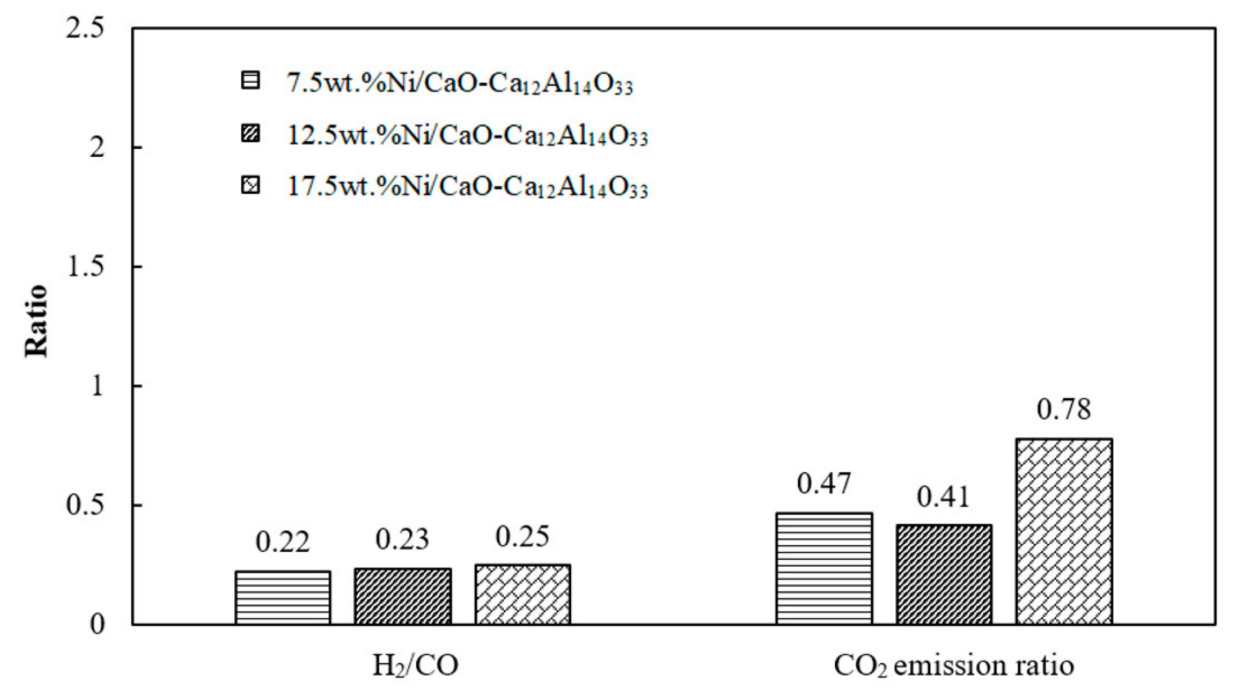

Figure 9. $\mathrm{H}_{2} / \mathrm{CO}$ and $\mathrm{CO}_{2}$ emission ratios at different wt. \% of $\mathrm{Ni}$ of $\mathrm{Ni} / \mathrm{CaO}-\mathrm{Ca}_{12} \mathrm{Al}_{14} \mathrm{O}_{33}$ using a $\mathrm{H}_{2} \mathrm{O}: \mathrm{CO}_{2}: \mathrm{O}_{2}: \mathrm{C}$ feed molar ratio of 0.5:0.1:0.125:1, gasification at $900{ }^{\circ} \mathrm{C}$, and SEWGS at $600{ }^{\circ} \mathrm{C}$.

\subsection{Effect of Sorption-Enhanced Water-Gas Shift (SEWGS) Temperature}

As seen from the previous section, combining gasification with SEWGS reaction with the use of 12.5 wt. $\% \mathrm{Ni} / \mathrm{CaO}-\mathrm{Ca}_{12} \mathrm{Al}_{14} \mathrm{O}_{33}$ can provide greater $\mathrm{H}_{2} / \mathrm{CO}$ ratio with lower $\mathrm{CO}_{2}$ emission. In this section, the effect of SEWGS temperature on $\mathrm{H}_{2} / \mathrm{CO}$ ratio and $\mathrm{CO}_{2}$ emission ratio was investigated. Figure 10 shows product compositions obtained at different SEWGS temperatures. Increasing SEWGS temperature from $500{ }^{\circ} \mathrm{C}$ to $650{ }^{\circ} \mathrm{C}$ does not affect the production of hydrogen or the quality of syngas, as comparative values are observed. The reduction of $\mathrm{CO}$ could be due to the reactions between $\mathrm{CO}$ and $\mathrm{H}_{2} \mathrm{O}$ (Equation (7)) and $\mathrm{CO}$ and $\mathrm{H}_{2}$ (reversed Equation (9)) which lead to the formation of $\mathrm{CH}_{4}$. Increasing temperature results in the decrease of $\mathrm{CH}_{4}$ due to exothermic reaction of Equation (9). The $\mathrm{CO}_{2}$ emission is found to decrease with increasing SEWGS temperature from 500 to $650{ }^{\circ} \mathrm{C}$ (Figure 11). This observation could be due to the result of the suitable $\mathrm{CO}_{2}$ sorption condition of $\mathrm{CaO}$ sorbent at a high temperature of $650^{\circ} \mathrm{C}[22,23]$.

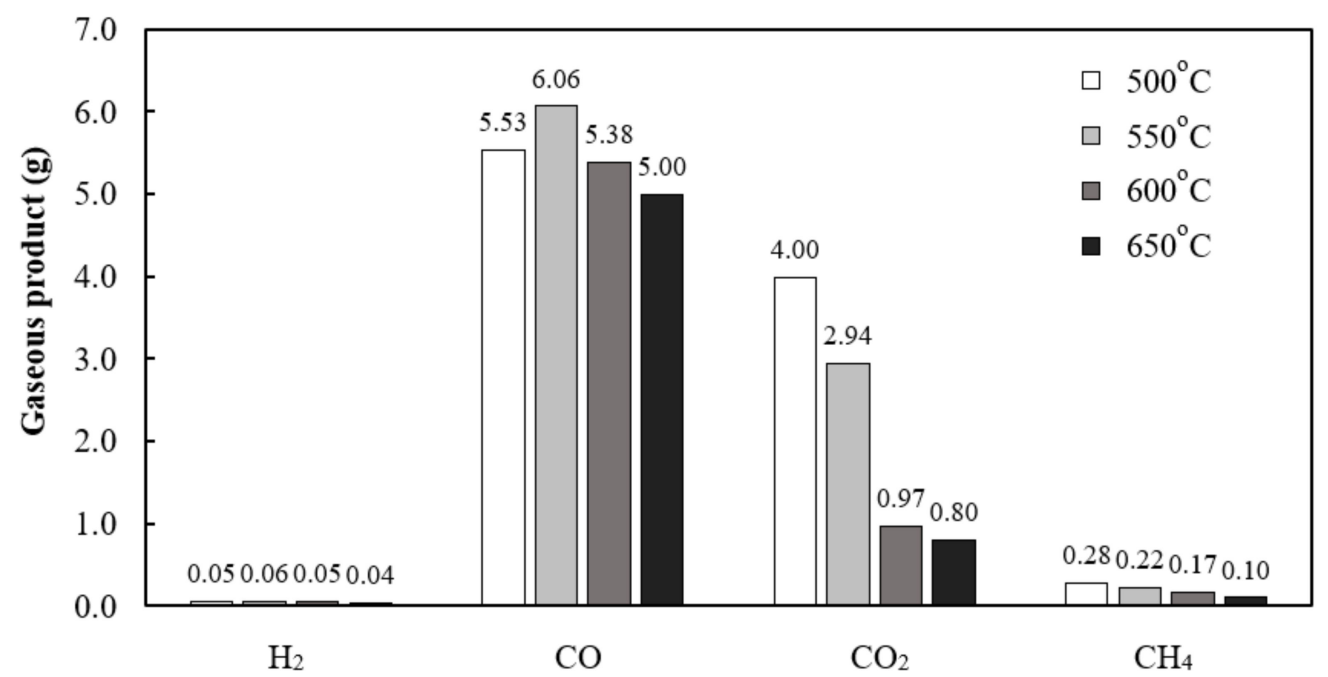

Figure 10. Product composition obtained from different SEWGS temperatures using a $\mathrm{H}_{2} \mathrm{O}: \mathrm{CO}_{2}: \mathrm{O}_{2}: \mathrm{C}$ feed molar ratio of 0.5:0.5:0.125:1 and gasification at $900{ }^{\circ} \mathrm{C}$. 


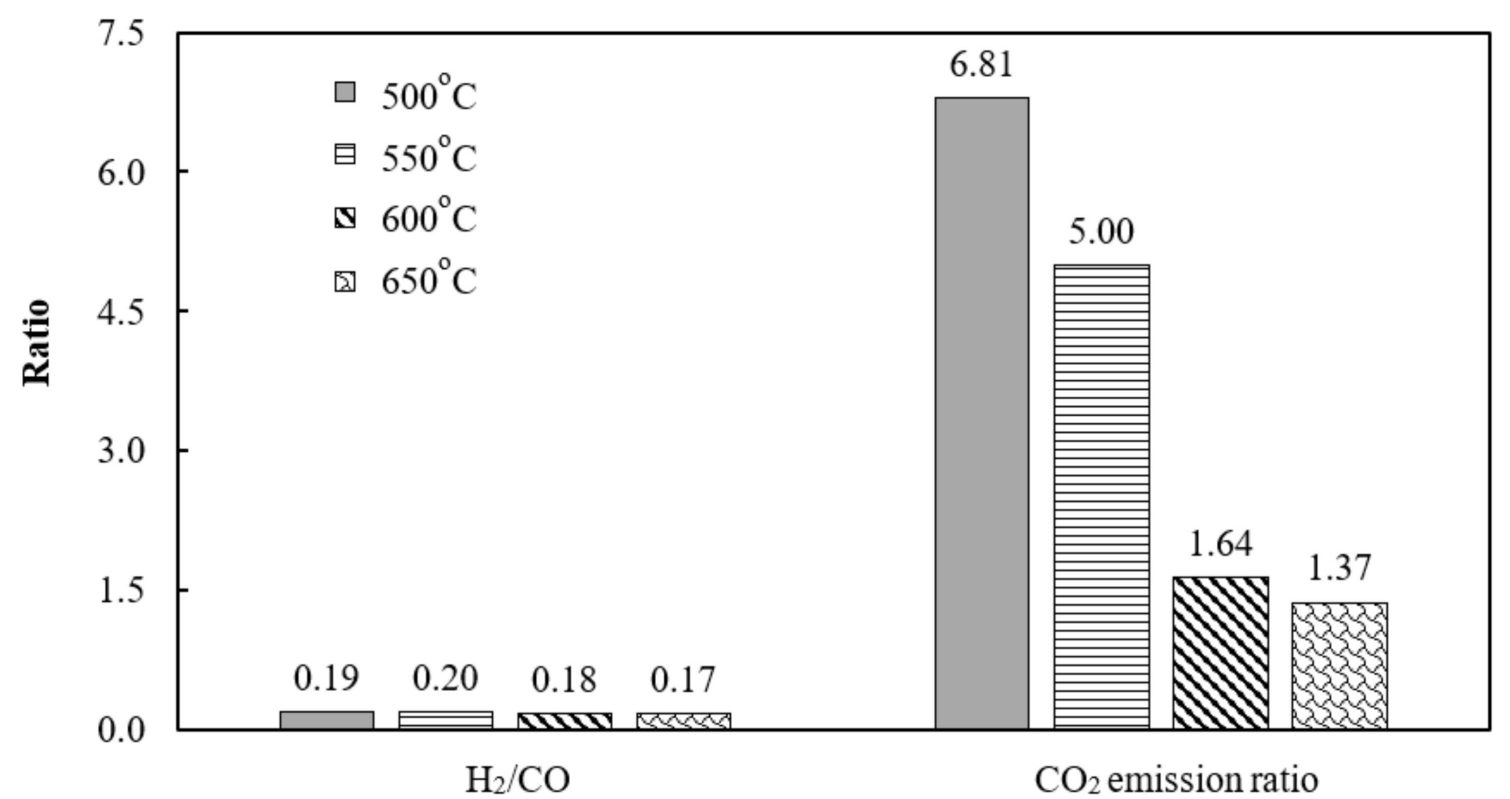

Figure 11. $\mathrm{H}_{2} / \mathrm{CO}$ and $\mathrm{CO}_{2}$ emission ratios at different SEWGS temperatures using a $\mathrm{H}_{2} \mathrm{O}: \mathrm{CO}_{2}: \mathrm{O}_{2}: \mathrm{C}$ feed molar ratio of 0.5:0.5:0.125:1 and gasification at $900{ }^{\circ} \mathrm{C}$.

$\mathrm{CO}_{2}$ reforming

$$
\mathrm{CH}_{4}(\mathrm{~g})+\mathrm{CO}_{2}(\mathrm{~g}) \rightleftharpoons 2 \mathrm{CO}(\mathrm{g})+2 \mathrm{H}_{2}(\mathrm{~g}) \quad \Delta H=247 \mathrm{~kJ} / \mathrm{kmol}
$$

\subsection{Effect of Gasifying Agent}

As the gasifying agent is one factor that can affect gasification of biomass [24], in this work, we investigated the effect of introducing $\mathrm{CO}_{2}$ as co-gasifying agent in order to utilize the $\mathrm{CO}_{2}$. The feed molar ratio of co-feed gasifying agent was fixed at $\mathrm{H}_{2} \mathrm{O}: \mathrm{O}_{2}: \mathrm{C}=0.5: 0.125: 1$, while the $\mathrm{CO}_{2} / \mathrm{C}$ molar ratio was varied between 0.1 and $0.5: 1$ using $12.5 \mathrm{wt} . \% \mathrm{Ni} / \mathrm{CaO}-\mathrm{Ca}_{12} \mathrm{Al}_{14} \mathrm{O}_{33}$ at a gasification temperature of $900{ }^{\circ} \mathrm{C}$ and SEWGS temperature of $600{ }^{\circ} \mathrm{C}$ (Section 3.5.1). And effect of $\mathrm{H}_{2} \mathrm{O}$ feed as gasifying agent was investigated by varying the $\mathrm{H}_{2} \mathrm{O}: \mathrm{C}$ ratio between $0.5-1.5: 1$ at a fixed $\mathrm{CO}_{2}: \mathrm{O}_{2}: \mathrm{C}$ feed molar ratio of 0.1:0.125:1, gasification temperature of $900{ }^{\circ} \mathrm{C}$, and SEWGS temperature of $600{ }^{\circ} \mathrm{C}$ (Section 3.5.2).

\subsubsection{Effect of $\mathrm{CO}_{2}$ Feed}

Figure 12 presents product composition obtained from the reaction with different amounts of $\mathrm{CO}_{2}$ feed. The results show that $\mathrm{CO}$ increases with increasing $\mathrm{CO}_{2} / \mathrm{C}$ ratio parallel with an increase of $\mathrm{CO}_{2}$ emission ratio (Figure 13). This observed result could be attributed to the reverse Boudouard reaction (Equation (1)). It is noted that although higher amounts of $\mathrm{H}_{2}$ produced from the system could be obtained due to the result of water-gas shift reaction, negligible amounts of produced $\mathrm{H}_{2}$ are still observed. This result might be because of insufficient steam feed into the system, leading to a smaller contribution of the water-gas shift reaction. Our observation is consistent with the results obtained from a thermodynamic study of lignite coal gasification reported by Kale et al. [25], where an increase of $\mathrm{CO}_{2} / \mathrm{C}$ feed mole ratio from 0 to 1 led to a decrease of $\mathrm{H}_{2} / \mathrm{CO}$ ratio from 3.04 to 0.7 . It is also noted that $\mathrm{CH}_{4}$ is observed in gaseous products, implying that reverse Boudouard reaction (Equation (1)) could occur due to the addition of $\mathrm{CO}_{2}$, resulting in higher production of $\mathrm{CO}$ which could further react with the produced $\mathrm{H}_{2}$ to form $\mathrm{CH}_{4}$ and $\mathrm{CO}_{2}$ (reversed Equation (9)). 


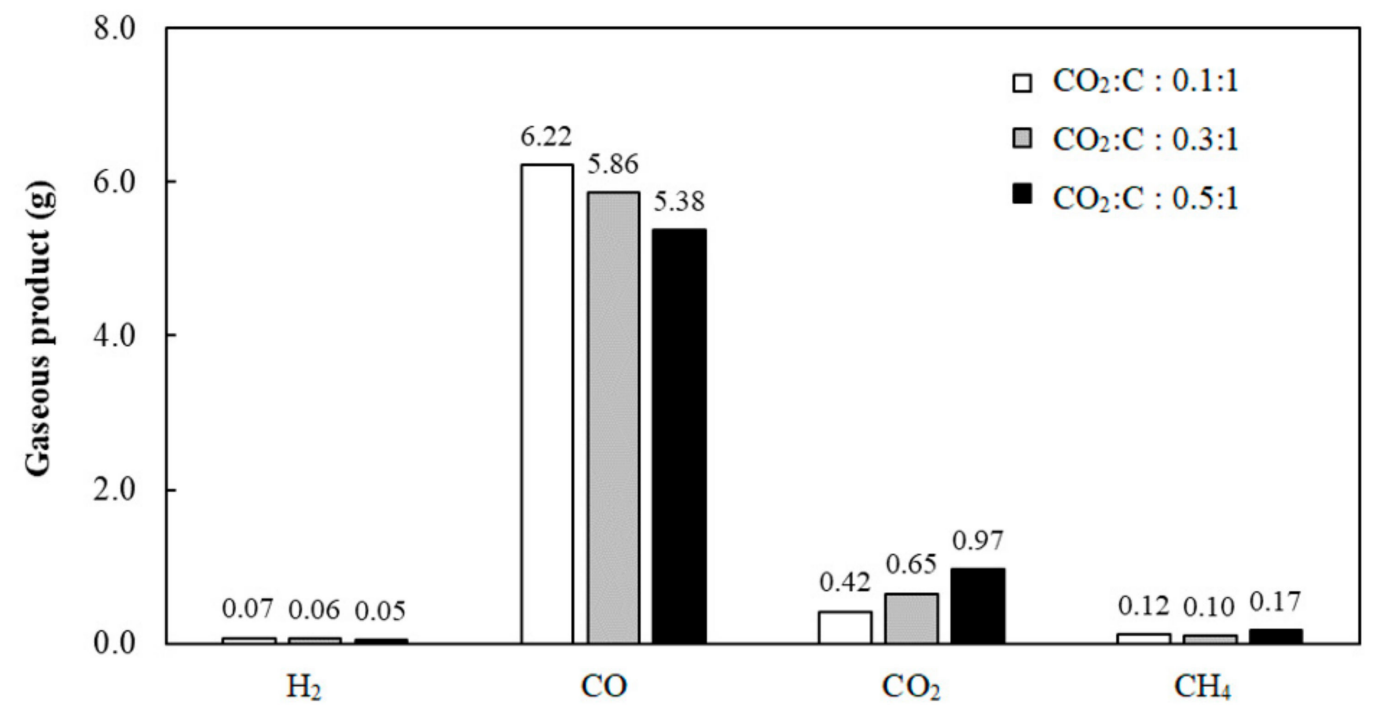

Figure 12. Product composition at different $\mathrm{CO}_{2}: \mathrm{C}$ ratios using a $\mathrm{H}_{2} \mathrm{O}: \mathrm{CO}_{2}: \mathrm{O}_{2}: \mathrm{C}$ feed molar ratio of 0.5:0.1-0.5:0.125:1, gasification at $900{ }^{\circ} \mathrm{C}$, and SEWGS at $600{ }^{\circ} \mathrm{C}$.

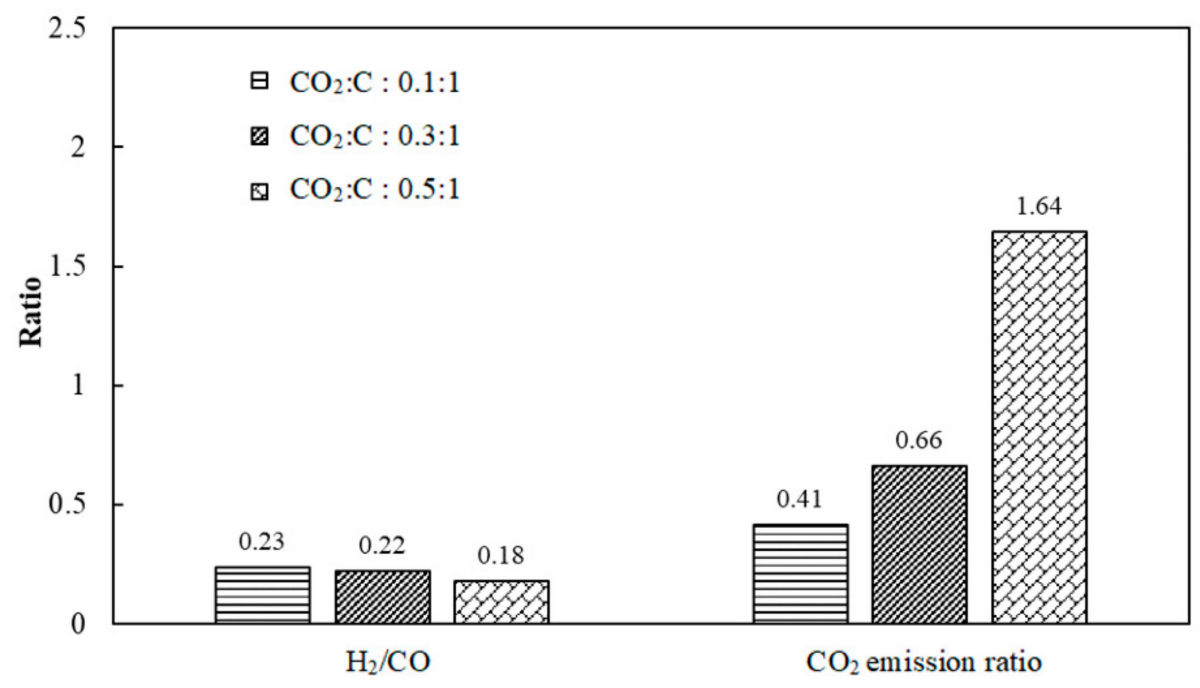

Figure 13. $\mathrm{H}_{2} / \mathrm{CO}$ and $\mathrm{CO}_{2}$ emission ratios at different $\mathrm{CO}_{2}: \mathrm{C}$ ratios using a $\mathrm{H}_{2} \mathrm{O}: \mathrm{CO}_{2}: \mathrm{O}_{2}: \mathrm{C}$ feed molar ratio of $0.5: 0.1-0.5: 0.125: 1$, gasification at $900{ }^{\circ} \mathrm{C}$, and SEWGS at $600{ }^{\circ} \mathrm{C}$.

\subsubsection{Effect of $\mathrm{H}_{2} \mathrm{O}$ Feed}

In Figure 14, increasing of $\mathrm{H}_{2} \mathrm{O}$ feed is expected to enhance the production of $\mathrm{H}_{2}$ due to a water gas reaction (Equation (4)) and water-gas shift reaction (Equation (7)); however, insignificant $\mathrm{H}_{2}$ production is observed. This result might be due to insufficient $\mathrm{H}_{2} \mathrm{O}$ feed as discussed previously. Nevertheless, quality of syngas $\left(\mathrm{H}_{2} / \mathrm{CO}\right.$ ratio) is found to increase with increasing $\mathrm{H}_{2} \mathrm{O}$ feed (Figure 15). This observation could possibly be due to the produced $\mathrm{CO}$ reacting with the produced $\mathrm{H}_{2}$ via the reversed $\mathrm{CO}_{2}$ reforming reaction (reversed Equation (9)) as evidenced by the reduction of $\mathrm{CO}$ and the increase of $\mathrm{CO}_{2}$ shown in Figure 14. 


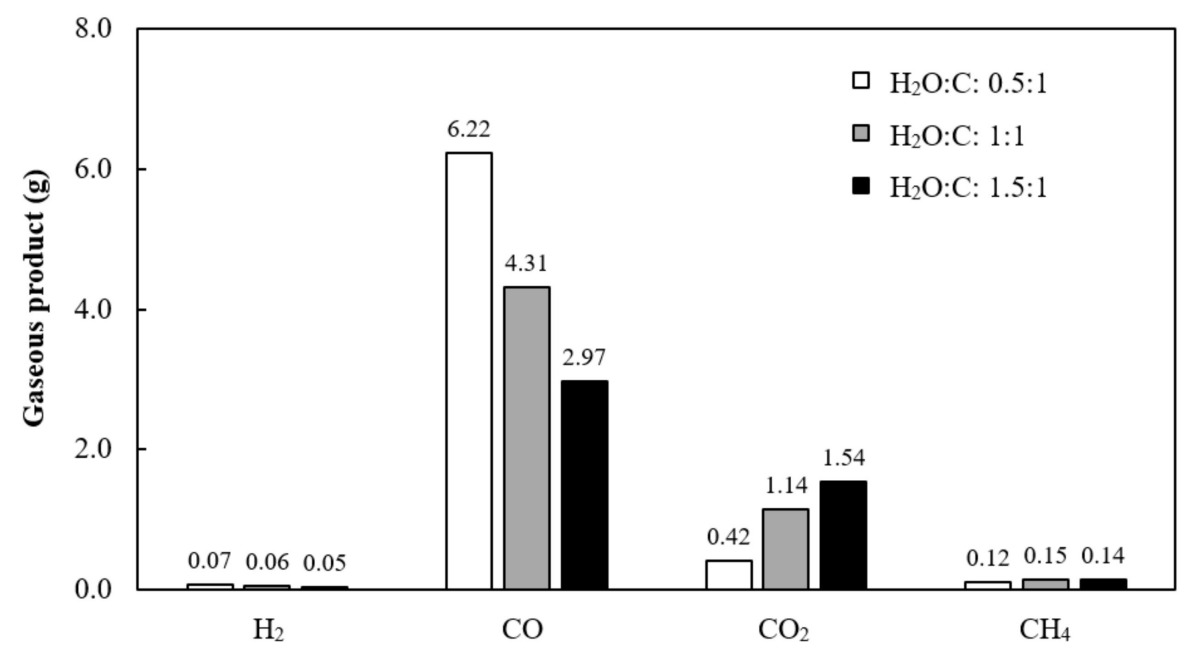

Figure 14. Product composition at different $\mathrm{H}_{2} \mathrm{O}: \mathrm{C}$ ratios using a $\mathrm{H}_{2} \mathrm{O}: \mathrm{CO}_{2}: \mathrm{O}_{2}: \mathrm{C}$ feed molar ratio of 0.5-1.5:0.1:0.125:1, gasification at $900{ }^{\circ} \mathrm{C}$ and SEWGS at $600{ }^{\circ} \mathrm{C}$.

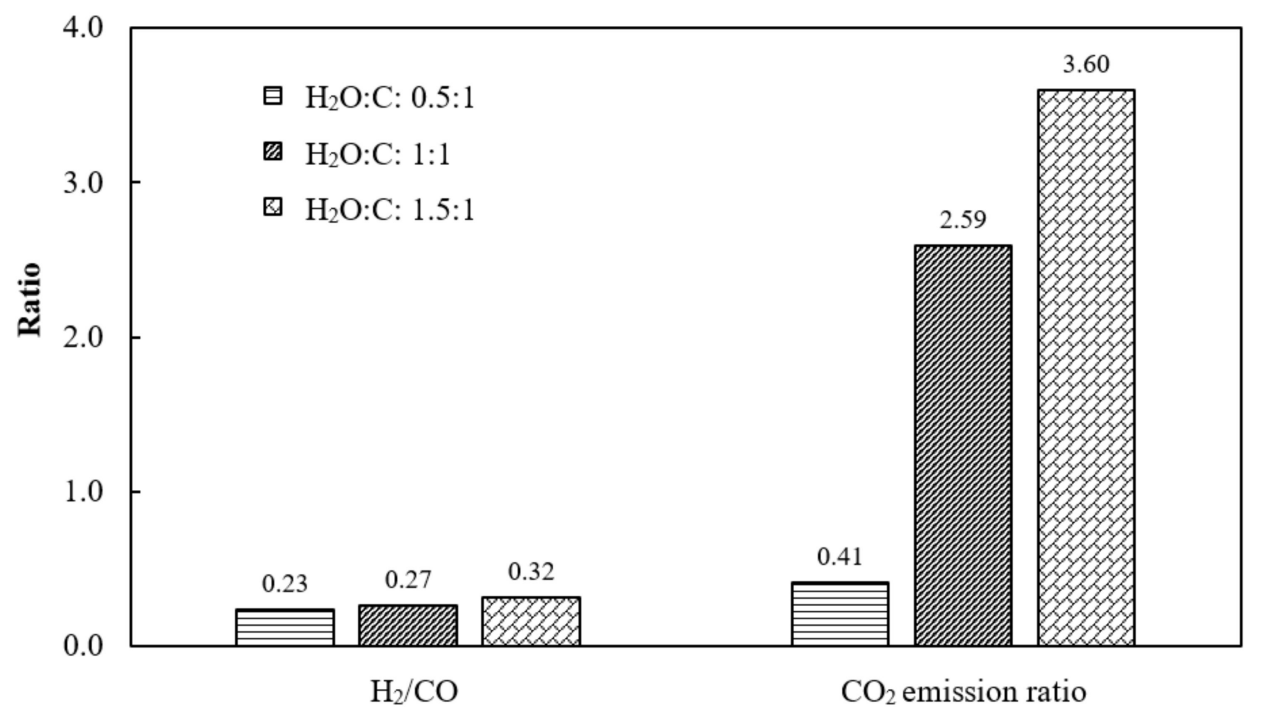

Figure 15. $\mathrm{H}_{2} / \mathrm{CO}$ and $\mathrm{CO}_{2}$ emission ratios at different $\mathrm{H}_{2} \mathrm{O}: \mathrm{C}$ ratios using a $\mathrm{H}_{2} \mathrm{O}: \mathrm{CO}_{2}: \mathrm{O}_{2}: \mathrm{C}$ feed molar ratio of 0.5-1.5:0.1:0.125:1, gasification at $900{ }^{\circ} \mathrm{C}$, and SEWGS at $600{ }^{\circ} \mathrm{C}$.

\section{Conclusions}

Our studies investigated the production of syngas from biochar using the combined gasification and sorption-enhanced water-gas shift reaction. The optimum gasification temperature was $900{ }^{\circ} \mathrm{C}$ with a $\mathrm{H}_{2} \mathrm{O}: \mathrm{O}_{2}: \mathrm{C}$ feed molar ratio of $0.25: 0.25: 1$. The one-body material combining catalyst with sorbent $\left(\mathrm{CBGR}-\mathrm{SimulCO}{ }_{2}\right.$ ) could provide the highest $\mathrm{H}_{2} / \mathrm{CO}$ ratio as well as the lowest $\mathrm{CO}_{2}$ emissions when compared to the other systems. In addition, the effect of sorption-enhanced water-gas shift temperature was shown to affect $\mathrm{CO}_{2}$ emissions. Increasing the operating temperature from 500 to $650{ }^{\circ} \mathrm{C}$ led to a decrease of the $\mathrm{CO}_{2}$ emission ratio. Increasing the $\mathrm{CO}_{2} / \mathrm{C}$ ratio from 0.1 to 0.5 resulted in an increase of $\mathrm{CO}$ production with a lower $\mathrm{CO}_{2}$ emission ratio. In addition, increasing the $\mathrm{H}_{2} \mathrm{O} / \mathrm{C}$ ratio from 0.5 to 1.5 provided higher syngas production, with $\mathrm{H}_{2} / \mathrm{CO}$ ratios of 0.23 and 0.32 , respectively.

Author Contributions: Conceptualization, Supawat Vivanpatarakij; Data curation, Supanida Chimpae, Suwimol Wongsakulphasatch, Supawat Vivanpatarakij and Fasai Wiwatwongwana; Formal analysis, Suwimol Wongsakulphasatch, Supawat Vivanpatarakij, Thongchai Glinrun and Weerakanya Maneeprakorn; Funding acquisition, Suttichai Assabumrungrat; Investigation, Supanida Chimpae and Thongchai Glinrun; Methodology, Supanida Chimpae, Suwimol Wongsakulphasatch and Supawat Vivanpatarakij; Project administration, Suttichai Assabumrungrat; Resources, Thongchai Glinrun, Fasai Wiwatwongwana and 
Weerakanya Maneeprakorn; Supervision, Suwimol Wongsakulphasatch, Supawat Vivanpatarakij and Suttichai Assabumrungrat; Validation, Thongchai Glinrun and Weerakanya Maneeprakorn; Writing-original draft, Supanida Chimpae, Suwimol Wongsakulphasatch, Supawat Vivanpatarakij and Suttichai Assabumrungrat.

Funding: The authors would like to acknowledge funding support from the Ratchadapisek Sompoch Endowment Fund 2016 of Chulalongkorn University (CU-59-003-IC), and King Mongkut's University of Technology North Bangkok (contract no. KMUTNB-KNOW-61-029). S.W. and S.A. also wish to acknowledge the "Research Chair Grant" of the National Science and Technology Development Agency (NSTDA).

Conflicts of Interest: The authors declare no conflict of interest.

\section{References}

1. Rodrigues, M.; Faaij, A.P.C.; Walter, A. Technol-economic analysis of co-fired biomass integrated gasification/combined cycle systems with inclusion of economies of scale. Energy 2003, 28, 1229-1258. [CrossRef]

2. Hamelinck, C.N.; Faaij, A.P.C.; den Uil, H.; Boerrigter, H. Production of FT transportation fuels from biomass; technical options, process analysis and optimization, and development potential. Energy 2004, 29, 1743-1771. [CrossRef]

3. Adams, T.A.; Hoseinzade, L.; Madabhushi, P.B.; Okeke, I.J. Comparison of $\mathrm{CO}_{2}$ capture approaches for fossil-based power generation: Review and Meta-study. Processes 2017, 5, 44. [CrossRef]

4. Acharya, B.; Dutta, A.; Basu, P. Chemical-looping gasification of biomass for hydrogen-enriched gas production with in-process carbon dioxide capture. Energy Fuels 2009, 23, 5077-5083. [CrossRef]

5. Pang, Y.; Hammer, T.; Müller, D.; Karl, J. Investigation of nonthermal plasma assisted charcoal gasification for production of hydrogen-rich syngas. Processes 2019, 7, 114. [CrossRef]

6. Chaiwatanodom, P.; Vivanpatarakij, S.; Assabumrungrat, S. Thermodynamic analysis of biomass gasification with $\mathrm{CO}_{2}$ recycle for synthesis gas production. Appl. Energy 2014, 14, 10-17. [CrossRef]

7. Kraisornkachit, P.; Vivanpatarakit, S.; Amornraksa, S.; Simasatitkul, L.; Assabumrungrat, S. Performance evaluation of different combined systems of biochar gasifier, reformer and $\mathrm{CO}_{2}$ capture unit for synthesis gas production. Int. J. Hydrog. Energy 2016, 41, 13408-13418. [CrossRef]

8. Ma, Z.; Zhang, S.; Xie, D.; Yan, Y. A novel integrated process for hydrogen production from biomass. Int. J. Hydrog. Energy 2014, 39, 1274-1279. [CrossRef]

9. Waheed, Q.M.K.; Williams, P.T. Hydrogen production from high temperature pyrolysis/steam reforming of waste biomass: Rice husk, sugar cane bagasse, and wheat straw. Energy Fuels 2013, 27, 6695-6704. [CrossRef]

10. Gao, N.; Lia, A.; Quan, C.; Gao, F. Hydrogen-rich gas production from biomass steam gasification in an updraft fixed-bed gasifier combined with a porous ceramic reformer. Int. J. Hydrog. Energy 2008, 33, 5430-5438. [CrossRef]

11. Liu, S.; Zhu, J.; Chen, M.; Xin, W.; Yang, Z.; Kong, L. Hydrogen production via catalytic pyrolysis of biomass in a two-stage fixed bed reactor system. Int. J. Hydrog. Energy 2014, 39, 13128-13135. [CrossRef]

12. Waheed, Q.M.K.; Wu, C.; Williams, P.T. Hydrogen production from high temperature steam catalytic gasification of bio-char. J. Energy Inst. 2016, 89, 222-230. [CrossRef]

13. Song, C.; Liu, Q.; Ji, N.; Deng, S.; Zhao, J.; Li, Y.; Song, Y. Alternative pathways for efficient $\mathrm{CO}_{2}$ capture by hybrid processes-A review. Renew. Sustain. Energy Rev. 2018, 82, 215-231. [CrossRef]

14. La Villetta, M.; Costa, M.; Massarotti, N. Modelling approaches to biomass gasification: A review with emphasis on the stoichiometric method. Renew. Sustain. Energy Rev. 2017, 74, 71-88. [CrossRef]

15. Indrawan, N.; Thapa, S.; Bhoi, P.R.; Huhnke, R.L.; Kumar, A. Engine power generation and emission performance of syngas generated from low-density biomass. Energy Convers. Manag. 2017, 148, 593-603. [CrossRef]

16. Ruiz, J.A.; Juárez, M.C.; Morales, M.P.; Muñoz, P.; Mendívil, M.A. Biomass gasification for electricity generation: Review of current technology barriers. Renew. Sustain. Energy Rev. 2013, 18, 174-183. [CrossRef]

17. Guohui, L.; Linjie, H.; Josephine, M.H. Comparison of reducibility and stability of alumina-supported Ni catalysts prepared by impregnation and co-precipitation. Appl. Catal. A 2006, 301, 16-24.

18. Cong, L.; Ying, Z.; Ning, D.; Chuguang, Z. Enhanced cyclic stability of $\mathrm{CO}_{2}$ adsorption capacity of CaO-based sorbents using $\mathrm{La}_{2} \mathrm{O}_{3}$ or $\mathrm{Ca}_{12} \mathrm{Al}_{14} \mathrm{O}_{33}$ as additives. Korean J. Chem. Eng. 2011, 28, 1042-1046.

19. Changjun, Z.; Zhiming, Z.; Cheng, Z.; Fang, X. Sol-gel-derived, $\mathrm{CaZrO}_{3}$-stabilized Ni/CaO-CaZrO 3 bifunctional catalyst for sorption-enhanced steam methane reforming. Appl. Catal. B 2016, 196, 16-26. 
20. Howaniec, N.; Smolinski, A.; Stanczyk, K.; Pichlak, M. Steam co-gasification of coal and biomass derived chars with synergy effect as an innovative way of hydrogen-rich gas production. Int. J. Hydrog. Energy 2011, 36, 14455-14463. [CrossRef]

21. Pan, X.; Miaomiao, X.; Zhenmin, C.; Zhiming, Z. $\mathrm{CO}_{2}$ capture performance of CaO-based sorbents prepared by a pol-gel method. Ind. Eng. Chem. Res. 2013, 52, 12161-12169.

22. Lu, H.; Reddy, E.P.; Smirniotis, P.G. Calcium oxide based sorbents for capture of carbon dioxide at high temperatures. Ind. Eng. Chem. Res. 2006, 45, 3944-3949. [CrossRef]

23. Yu, C.H.; Huang, C.H.; Tan, C.S. A review of $\mathrm{CO}_{2}$ capture by absorption and adsorption. Aerosol Air Qual. Res. 2012, 12, 745-769. [CrossRef]

24. Butterman, H.C.; Castaldi, M.J. $\mathrm{CO}_{2}$ as a carbon neutral fuel source via enhanced biomass gasification. Environ. Sci. Technol. 2009, 43, 9030-9037. [CrossRef] [PubMed]

25. Kale, G.R.; Kulkarni, B.D.; Chavan, R.N. Combined gasification of lignite coal: Thermodynamic and application study. J. Taiwan Inst. Chem. Eng. 2013, 45, 163-173. [CrossRef]

(C) 2019 by the authors. Licensee MDPI, Basel, Switzerland. This article is an open access article distributed under the terms and conditions of the Creative Commons Attribution (CC BY) license (http://creativecommons.org/licenses/by/4.0/). 